\title{
ОЦЕНКА ЭКОЛОГИЧЕСКОГО СОСТОЯНИЯ ЛЕСОПАРКА «КУСКОВО» Г. МОСКВЫ ПО ФЛУКТУИРУЮЩЕЙ АСИММЕТРИИ ЛИСТЬЕВ КЛЕНА ОСТРОЛИСТНОГО
}

\section{ASSESSMENT OF THE ECOLOGICAL STATE OF THE KUSKOVO FOREST PARK IN MOSCOW BASED ON THE FLUCTUATING ASYMMETRY OF THE LEAVES OF THE HOLLY MAPLE \\ E. Makarova E. Grinko}

Summary. This article discusses one of the methods of biological indication of the environment by fluctuating asymmetry of leaves. The results of statistical processing of leaf plates of acorn maple (Acer platanoides L.) are presented and the state of the natural environment of the Kuskovo forest Park in Moscow is assessed.

Keywords: bioindication, fluctuating asymmetry method, environment, holly maple.
B озрастание антропогенной (техногенной) нагрузки в крупных городах приводит к негативным изменениям в структуре, продуктивности и функциональным нарушениям экосистем: уменьшается численность видов растений и животных, приводящая к снижению биоразнообразия в целом, нарушаются природные ландшафты и гидрологический режим местности, развивается эрозия почв. Мониторинг уровня загрязнения и ответной реакции биологических объектов на внешнее воздействие приобретает огромное значение.

Bсе более усиливающаяся техногенная нагрузка на окружающую природную среду приводит к появлению новых параметров среды, а также, обуславливает антропогенную модификацию имеющихся природных факторов, а, следовательно, и изменение свойств биологических систем. Биологическая индикация позволяет получить информацию о реакциях организмов на стрессорные факторы и дает возможность проследить последствия антропогенного воздействия на окружающую среду и глубину изменений происходящих на уровне экосистем. Живые организмы реагируют на изменение условий среды, в том числе и неблагоприятных, изме-

\author{
Макарова Елена Александровна \\ К.б.н., дочент, Московская государственная \\ академия ветеринарной медицины и биотехнологии \\ имени им. К.И. Скрябина \\ lelemakarov@mail.ru \\ Гринько Екатерина Константиновна \\ Московская государственная академия \\ ветеринарной медицины и биотехнологии имени \\ им. К.И. Скрябина
}

Аннотация. В данной статье рассматривается один из методов биологической индикации окружающей среды по флуктуирующей асимметрии листьев. Представлены результаты статистической обработки листовых пластин клена остролистного (Acer platanoides L.) и проведена оценка состояния окружающей природной среды лесопарка «Кусково» г. Москвы.

Ключевые слова: биоиндикация, метод флуктуирующей асимметрии, окружающая среда, клен остролистный.

нением своего состояния, поведения или определенными действиями. Организмы способны к преодолению неблагоприятных воздействий двумя путями: избегать такого воздействия или приобретать выносливость. Так как, растения лишены возможности избегать негативных факторов, основной стратегией их жизни является адаптация к неблагоприятным условиям за счет выработки различных приспособлений проявляющихся в изменении процессов жизнедеятельности, изменения строения и др. [6].

Флуктуирующая асимметрия есть проявление индивидуальной изменчивости, которая отражает различия между гомологичными структурами внутри одного индивида. Такой тип изменчивости характерен для растений, когда в пределах одного индивида, можно провести комплексный анализ метамерных структур, при этом наиболее часто используют листовые пластины. Так как уровень флуктуирующей асимметрии есть характеристика индивидуума, следовательно, можно оценить различие разных групп особей по среднему уровню асимметрии между сторонами, и тогда флуктуирующая асимметрия может рассматриваться и с позиции надындивидуальной (популяционной) изменчивости [3]. 
На данный момент оценка экологического состояния городских лесопарковых территорий является важным показателем, дающим возможность определить уровень антропогенных воздействий на экосистемы парков и приблизительно определить степень их нарушенности на исследуемой территории.

Одна из известных методик, позволяющих определить экологическое состояние территорий по асимметрии листьев растений - методика А.С. Боголюбова [1]. В основу данной методики положена теория о том, что различие между левой и правой половинами листовой пластины коррелирует со степенью общей нарушенности окружающей среды. Такая методика может быть использована для оценки экологического состояния территории по интегральным характеристикам асимметрии листьев деревьев [1].

Целью работы является оценка экологического состояния лесопарковой зоны «Кусково» и обнаружение изменений морфогенетических процессов на примере показателей флуктуирующей асимметрии листьев клена остролистного (Acer platanoides), в норме обладающих билатеральной симметрией.

Для исследования был выбран участок ВАО города Москвы - лесопарк «Кусково» который занимает площадь чуть более 300 га и находится в пределах Мещёрской низменности, являясь частью района Вешняки Восточного административного округа города. Основная часть насаждений лесопарка представлена березняками, значительная площадь занята старыми разреженными дубами и липами, часто встречаются клены, ели и лиственница. В лесопарке «Кусково» произрастают редкие для столицы растения, занесенный в Красную книгу Москвы, обитает 7 видов млекопитающих и более 60 видов птиц.

Основными источниками антропогенного воздействия на территории природного комплекса представляющими определенную экологическую опасность являются выбросы автомобильного транспорта по ближайшим улицам: Оранжерейной, Вешняковской, ул. Первой Маёвки, Рассветной, 1-му Дворцовому проезду и Аллее Жемчуговой. Кроме этого, техногенное воздействие также оказывают предприятие дорожно-эксплуатационного комплекса по обслуживанию 3-го транспортного кольца, база хранения реагентов ВАО, складская база вторсырья. Источниками антропогенного воздействия на лесопарковую зону являются различные промышленно-коммунальные объекты (автозаправочные станции, автомойки, автостоянки, гаражи, железная дорога и др.), расположенные на прилегающих к лесопарковой зоне территориях.

Для сбора материала были выбраны три участка лесопарка «Кусково». Первый находится на окраине парка, у выхода с платформы Плющево, где проходит магистральная улица общегородского значения Северо-Восточная хорда и железнодорожные пути. Здесь постоянный шум от проезжающего автомобильного транспорта и проходящих поездов ближнего и дальнего следования. Отчетливо ощущается запах канализации. В пределах видимости находится ТЭЦ-11.

Второй участок расположен в глубине парка на расстоянии 700 метров по диагонали от первого. Характеризуется отсутствием дорог в зоне видимости и других антропогенных объектов способных загрязнять природную среду.

Третий находится в глубине парка, в 660 м от второго участка, в 330 м от Большого Дворцового пруда. Здесь также отсутствуют техногенные объекты, достаточно тихо, не слышно дорожного шума и посторонних запахов.

На каждом из выбранных участков были собраны листья клена остролистного с трех деревьев, расположенных друг от друга в 100 м, по десять листьев с каждого, т.е. всего 30 листьев с одной площадки.

Собирали листья на каждом опытном участке из средней части кроны каждого дерева, на уровне поднятой руки, с доступных веток, примерно одного, среднего размера.

С каждого листа были сняты показатели по четырем параметрам с левой и правой стороны листа:

1 - ширина половинки листа. Для измерения лист складывают поперек пополам, прикладывая макушку листа к основанию, потом разгибают и по образовавшейся складке производят измерения;

2 - длина второй жилки второго порядка от основания листа;

3 - расстояния между концами первой и второй жилки;

4 - угол между главной жилкой и второй от основания жилки первого порядка.

Величину асимметричности оценивали при помощи интегрального показателя величины среднего относительного различия на признак (средняя арифметическая отношения разности к сумме промеров листа слева и справа, отнесенная к числу признаков). Относительную величину между значениями признака с каждой из сторон (Y) находили применяя формулу: $Y=(X л-X n) /(X л+X n)$, а среднее относительное различие между сторонами в соотношении к признаку каждого листа рассчитывали: $(Z)-Z=(Y 1+Y 2+Y 3+Y 4) / N$, где $N-$ число признаков.

Среднее относительное различие, деленное на признак для всей выборки $(X)$, вычисляли используя форму- 
Таблица 1. Шкала отклонения от нормы

\begin{tabular}{|l|l|l|}
\hline Баллы & Значение показателя асимметричности & Экологическое состояние \\
\hline 1 балл & $<0,015$ & Условная норма \\
\hline 2 балла & $0,016-0,025$ & Начальные незначительные отклонения \\
\hline 3 балла & $0,026-0,035$ & Начальные значительные отклонения \\
\hline 4 балла & $0,036-0,045$ & Начальное критическое состояние \\
\hline 5 балла & $0,046-0,055$ & Критическое состояние \\
\hline
\end{tabular}

Таблица 2. Флуктуирующая асимметрия листовой пластины клена остролистного.

\begin{tabular}{|l|l|l|}
\hline Участок & Показатель асимметричности клена остролистного & Баллы \\
\hline 1 & 0,067188 & 5 \\
\hline 2 & 0,02557 & 3 \\
\hline 3 & 0,01656 & 2 \\
\hline
\end{tabular}

лу: $X=Z / n=(Z 1+Z 2+\ldots+Z n) / n$, где $n-$ число значений $Z$ (число листьев). Обработка результатов проводилась при помощи таблиц Microsoft Office Excel.

Полученные в результате расчетов показатели характеризуют степень асимметричности и для этого показателя существует разработанная пятибалльная шкала отклонения от нормы [3], в которой каждый балл характеризует экологическое состояние организма (1 балл считается условной нормой, а 5 баллов свидетельствует о критическом состоянии).

В результате проведенного исследования был произведен расчет и оценка различных морфологических показателей листьев клена остролистного (Acer platanoides L.).

Анализируя полученные данные по относительному различию между значениями признака слева и справа (Y) для каждого показателя, высоким значением различия в ширине половинок листа (1 признак) обладают клены первого участка $(0,159)$, значительно ниже этот показатель на третьем участке $(0,084)$. Различия в длине 2-й жилки (2 признак) изменялись в пределах от 0,037 (первом участке) до 0,018 (второй участок). При измерении расстояния между концами 1-й и 2-й жилок (3 признак) выявлено, что разница в значениях этих показателе проявлялась у листьев с первого и третьего участков и составляла 0,121 и -0,018 соответственно. Угол между центральной и 2-й жилкой первого порядка (4 признак) колебался в интервале от 0,0361 (первый участок) до 0,008 (третий участок).

По полученным данным была составлена таблица 2 - флуктуирующей асимметрии клена остролистно- го на исследуемых участках и графическое изображение распределения данного показателя в зависимости от удаленности антропогенных объектов.

Условной нормой можно считать показатель меньше, чем 0,015. Таким образом, на всех исследуемых участках показатель отклоняется от условной нормы, а на первом участке характеризуется критическими значениями отклонения.

На втором участке этот показатель равен 3 баллам, что соответствует начальным значительным отклонениям, а на третьем равен 2 баллам, что характеризуется как начальные незначительные отклонения. Таким образом четко прослеживается зависимость между степенью асимметрии листьев клена остролистного и удаленностью деревьев от антропогенных загрязнителей среды (рис 1).

Из рисунка видно, что с продвижением вглубь парка, негативное влияние этих загрязнителей ослабевает, но тем не менее можно говорить о высокой степени загрязненности исследуемой территории лесопарка. Показатели флуктуирующей асимметрии, отражающие экологическое состояние деревьев, в том числе и кленов, в лесопарковой зоне, варьируют в пределах от - 0,067 до 0,016 и превышают условную норму $(<0,015)$ на всех исследуемых участках лесопарка.

Таким образом, оценка состояния окружающей среды с использованием методов биоиндикации и, в том числе, флуктуирующей асимметрии листьев дает возможность оценить влияние антропогенной нагрузки на живые организмы и сделать выводы о зависимости уровня загрязнения и нарушенности экосистем лесопарковых зон города. 


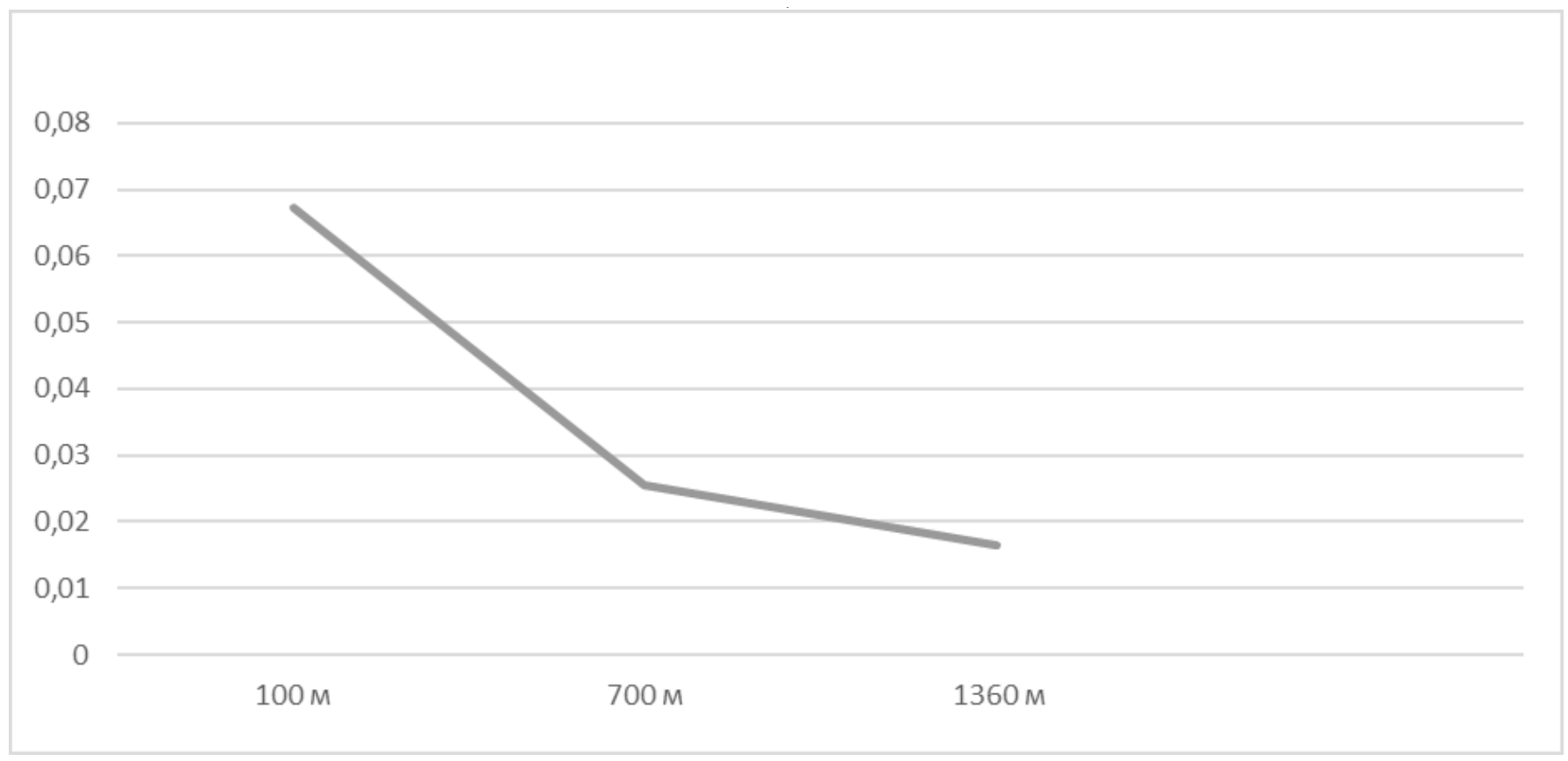

Рис. 1. Степень асимметрии листьев клена остролистного (Acer platanoides L.) и удаленность от антропогенных объектов

Детальный анализ влияния антропогенных стрессовых факторов и, в первую очередь, таких, как выхлопные газы автомобильного транспорта и большая выборка листьев клена, собранных в различных парках города позволит провести более глубокий анализ благополучия городских экосистем, составить корреляционные связи между уровнями загрязненности улиц вокруг лесопарковых зон города и флуктуирующей симметрией листьев.

\section{ЛИТЕРАТУРА}

1. Боголюбов А. С. Оценка экологического состояния леса по асимметрии листьев / А. С. Боголюбов.—М.: Экосистема, 2002.— 10 с.

2. Вайнерт Э. Биоиндикация загрязнений наземных экосистем / Э. Вайнерт, Р. Вальтер, Т. Ветцель. и др.; Под ред. Р. Шуберта; Пер. с нем. Г. И. Лойдиной, В. А. Турчаниновой; Под ред. Д. А. Криволуцкого.- М.: Мир, 1988. - 348 с.

3. Захаров В. М. Здоровье среды: методика оценки / В. М. Захаров, Ю. А. Буйлов, М. В. Кравченко.— М.: Центр экологической политики России, 2000-68 с.

4. Захаров В. М. Онтогенез и популяция (стабильность развития и популяционная изменчивость) / В. М. Захаров // Экология.— Екатеринбург, 2002.— № 3 - C. 164-168.

5. Ломсков М. А., Таратоненкова М. А. Исследование состояния древостоя на модельных площадках парка Царицыно с помощью метода флуктуирующей асимметрии / Рост и воспроизводство научных кадров в АПК. Сборник трудов по итогам Российской национальной научно-практической интернет-конференции для обучающихся и молодых ученых. Под общей редакцией Н. Н. Бессчетновой. 2020. С. 150-154.

6. Ляшенко 0. А., Биоиндикация и биотестирование в охране окружающей среды: учебное пособие / 0. А. Ляшенко — СПб ГтУРП. — СПб, 2012 . - 67 с.

7. Макарова Е. А., Гринько Е. К. Флуктуирующая асимметрия листьев как метод биоиндикации для определения уровня загрязнения среды // Проблемы зоокультуры и экологии. Вып. 3.- М.: ГАУ «Московский зоопарк»; ЕАРАЗА; СОЗАР: Изд. «ЗооВетКнига», 2019.— 191-195 с.

8. Мелькумов Г. М., Волков Д. Э. Флуктуирующая асимметрия листовых пластинок клена остролистного (Acer platanoides L.) как тест экологического состояния паркоценозов городской зоны. // Журнал Вестник ВГУ. Серия: География. Геоэкология.— Воронеж, 2014, № 3, 95 -98 c. 